\title{
Accounting Engineering and Management of Results
}

\author{
Laura-Maria Popescu and Ileana Nișulescu-Ashrafzadeh
}

\begin{abstract}
Accounting means normally a basis while making management decisions; it is the information tool in order to highlight the strategies and to confirm their success. There are also cases where the roles are reversed and the management delineates the accounting directions according to the results obtained, thus being transformed from the company management for results to the results themselves. Even if over time, the information and activity monitoring techniques improved, the precision of the economic and financial data remains dependent on the reporting referential and the manipulation technique of the results. The article is meant to highlight the items capable to characterise the choice of a management based on results, the conditions of its development, how the financial and accounting information users are affected, particularly the investors, as well as how it can be detected. It is also highlighted the fact that the management based on results plays a very important role for the apparition and development of the accounting engineering at the level of company by the determination it exercises over the managers while achieving or surpassing the objectives. Thus, there is the issue of a false reflection of the company's activity, regarded by the prism of the management objectives, making particularly sensitive the passage from the economic reality of the company to the management ideals of the management. The financial and accounting information remains as main source of reflection of the economic activity and of the results of these activities, both for the own managers of the entities and for the large diversity of third parties: providers, customers, employees, investors, banks, State institutions etc., that makes it vulnerable in front of the external actions. It is important that in any management plan, its accounting represents a source of information for the management and not a means of obtaining the results.
\end{abstract}

Index Terms-Financial and Accounting Engineering, Management of Results, Performances, Accounting Information.

\section{INTRODUCTION}

Sometimes accounting is considered a science and other times an art and it managed to induce in the economists' world a special trust. The general idea is that the accounting science is very exact, just like mathematics. In fact, the accounting information is neither simple nor precise and it rarely meets all the requirements of the different users.

Accounting is the representation tool of a company, the financial ratio based on the accounting principles and which must provide the reliable image of reality. But sometimes the accounting information is deformed, so the users' behaviour is manipulated. The responsible persons who control the form and content of the financial statements made by the corporation will ensure that they will form in

Published on July 19, 2019

Authors are with the Academy of Economic Studies, Bucharest, Romania.

JEL Classification: M40 general an image favourable to them, by means of creativity and or artistic skills.

The result reported has a major influence on the activities carried out by a company and on the decisions taken by its management. Thus, the management of a company may find itself thinking that its role is that of making all that it is possible to ensure the accomplishment or the surpassing of the analysts' predictions, intending to manage the gains. The accomplishment of the predictions is only one of the multiple reasons which may affect the management behaviour and may advance the idea of management of results. There are other objectives arising, such as the need to support the success of a public tender initiated, a maximum level of the result required to obtain a stimulatory reimbursement or the achievement of a threshold related to a financial understanding.

The article wants to discover how much the management of results is used by the company management, the motivation of using these practices and the items capable to positively or negatively influence the companies.

The research method used is based on the data of secondary sources, that is documentation. We chose this method because it presents certain advantages for the ongoing research: it allows an efficiency in getting information, it provides the possibility to confront the information it provides, so increasing the level of trust, it involves a less effort to collect the data, the information obtained have a more accentuated objective character and in certain cases unique, providing information which is unavailable in other cases. The main secondary sources used have been the external sources such as the official documents, the magazines and the specialised publications, the statistic censuses, the press, the Internet, the documents of the different companies analysed and the specialised literature.

The research tool used within the study has been the identification and analysis of the data obtained after documentation and their grouping according to the importance and relevance for the subject of the article.

Over time, there were made a series of studies by which it was tried to define the concept of management of results. Even if there were not very numerous, they formed around the idea that the management of results represent the manipulation of the accounting results in order to create a modified impression on the performances of the company (C. Mulford and E. Comiskey, 1996). In 1997, W. Scott asserted that the choice of the accounting policies to maximise his activity, highlights the idea of management of results. The year 1999 brought to public attention the reporting issued arisen among the public companies, because of the abusive management, in order to obtain the result desired. The rollup point of the studies made on this subject is given by the idea of modified results and the fact 
that the companies initiate such practices to create certain performances which would have not arisen if there were no users.

The idea of reality has no place in the management of results, those who are using these practices present a reality only viewed by them, by presenting the items which support the favourable side of the financial and accounting activity. Thus it is wanted for the users to create an illusion, by which to provide trust within the company. It may be possible by presenting in a subjective way the accounting and financial activity.

The apparition of such practices is based on the creation of several conditions for their development, such as poor internal controls, management with no experience, the weak education of the board of directors or the existence of complex transactions. In the table below, there are detailed the adequate conditions for the development of the management of results and how they are stimulated:

TABLE I: STIMULATION AND DEVELOPMENT OF THE MANAGEMENT OF RESULTS

\begin{tabular}{|c|c|}
\hline Conditions & Stimulating items \\
\hline $\begin{array}{l}\text { Lower results than the average } \\
\text { result expected per action; }\end{array}$ & $\begin{array}{l}\text { Avoiding a rapid decrease of the } \\
\text { action price; }\end{array}$ \\
\hline $\begin{array}{l}\text { Preparing for an initial public } \\
\text { offer of its actions; }\end{array}$ & $\begin{array}{l}\text { Presenting a favourable image on the } \\
\text { results in order to maximise the price } \\
\text { at which the shares issued are sold; }\end{array}$ \\
\hline $\begin{array}{l}\text { Obtaining financial stimulation } \\
\text { reimbursements following the } \\
\text { range of the results over or below } \\
\text { a certain level; }\end{array}$ & $\begin{array}{l}\text { Ranging the results between the } \\
\text { minimal level and maximal one, in } \\
\text { order to maximize the stimulation } \\
\text { reimbursements; }\end{array}$ \\
\hline $\begin{array}{l}\text { The number of members makes } \\
\text { the company to be vulnerable in } \\
\text { front of the unfavourable policy } \\
\text { activity; }\end{array}$ & $\begin{array}{l}\text { Minimising the politic costs relating } \\
\text { to the number of members, in order to } \\
\text { avoid for the profit level to be } \\
\text { considered excessive; }\end{array}$ \\
\hline $\begin{array}{l}\text { complying } \\
\text {; }\end{array}$ & $\begin{array}{l}\text { Avoiding the unfavourable effects, as } \\
\text { increasing the interest rate, an } \\
\text { immediate reimbursement demand } \\
\text { etc. }\end{array}$ \\
\hline $\begin{array}{l}\text { The results are not ranged in the } \\
\text { tendency given by the } \\
\text { management as duration, long } \\
\text { term; }\end{array}$ & $\begin{array}{l}\text { Avoiding an answer for the results } \\
\text { which are temporarily outside the } \\
\text { tendency; }\end{array}$ \\
\hline $\begin{array}{l}\text { Volatility of the results following } \\
\text { the events which are not usually } \\
\text { produced; }\end{array}$ & $\begin{array}{l}\text { One acts to reduce the volatility in } \\
\text { order to avoid such a penalty } \\
\text { associated to a risk; }\end{array}$ \\
\hline $\begin{array}{l}\text { A change of the company's } \\
\text { management; }\end{array}$ & $\begin{array}{l}\text { Initiation of massive cancels in order } \\
\text { to highlight the future results, by the } \\
\text { fault of the previous management; }\end{array}$ \\
\hline $\begin{array}{l}\text { Existence of massive losses due } \\
\text { to the expenditures with the past } \\
\text { restructuring. }\end{array}$ & $\begin{array}{l}\text { Using the provisions in order to } \\
\text { achieve the results wanted during the } \\
\text { next periods. }\end{array}$ \\
\hline
\end{tabular}

Source: Created by the author

The techniques of the management of results involve the use of the current flexibility in the accounting standards and are grouped in the following categories:

- Changing the amortisation methods, the useful durations of life and the residual values for amortisation;

- Determining the non-collection degree for the amounts unrecovered or the intangible debts, the damaging degree of the warranty obligations, of the part of the price of a procurement which may be shared on research and development projects;

- The estimation of the reduction for certain investments, of the restructuring provisions and of those relating to medium term obligations, of the possibilities to meet the contractual requirements and the identification of the depreciated assets;

- Establishing the need of stocks and their depreciation, of the amortisation periods of the tangible assets, of capitalisation of the costs or the influence exercised by an investment in the company.

The use of the management of results may have both negative and positive effects, everything depends on how much the techniques are used and on the end purpose, in order to have the priority of the company interest, and not of the management one. When the image of a company is not significantly distorted, the practices of this type may help the company to get rid of a financial impasse, so highlighting a positive side of their used. But frequently the managers have understood to manipulate the company's results for their own benefit, so bringing the company to bankruptcy. In the table there are mentioned a series of aspects of the use of the management of results and of the influence they exercise both for a company and for an external environment:

TABLE II: NEGATIVE AND POSITIVE ITEMS OF THE MANAGEMENT OF RESULTS

\begin{tabular}{cc}
\hline Negative Items & Positive Items \\
\hline $\begin{array}{c}\text { - Distorting the financial performance } \\
\text { by hiding the economic reality of the } \\
\text { company and minimising the business } \\
\text { risk; covering the negative tendencies } \\
\text { and creating the impression of a larger } \\
\text { stability than the real one. }\end{array}$ & $\begin{array}{c}\text { - Reducing the volatility of the } \\
\text { results, which create an } \\
\text { indicator of the financial force } \\
\text { and has the effect of increasing } \\
\text { the benefits, by the idea of } \\
\text { perception of the results as } \\
\text { being less risky. }\end{array}$ \\
$\begin{array}{cc}\text { - Increasing or decreasing the price of } \\
\text { the shares by its artificial increase, } \\
\text { followed by an unexpected decrease, } \\
\text { thus reducing the trust in the figures } \\
\text { reported }\end{array}$ & $\begin{array}{c}\text { - Providing a benefit as the price } \\
\text { of the share by the stabilisation } \\
\text { of the investment advantages } \\
\text { and contributing in this way to } \\
\text { maintain the stabilisation of } \\
\text { their price. }\end{array}$ \\
$\begin{array}{c}\text { - Affecting in a negative way the } \\
\text { company's performance by providing } \\
\text { several excessive reimbursements to } \\
\text { the management, the inadequate use of } \\
\text { the resources or making decisions } \\
\text { shortly for the detriment of the long } \\
\text { term ones }\end{array}$ & $\begin{array}{c}\text { predictions and to rationalise the } \\
\text { expectations, considering that } \\
\text { the predictions of the analysts } \\
\text { are very important nowadays. }\end{array}$ \\
\hline \hline
\end{tabular}

Source: Mentioned by the author

The efficiency of the management of results depends on combining the techniques used, so their detection may be simple by following several items, such as changes of accounting policies and practices, the absence or subassessment of predictions, the aggressive capitalisation of expenditures, the optimistic reimbursement, the sale of debts, fictive registrations or the registration of the expenditures and revenues according to the activity of the previous years.

Very many times, the detection of the management of results may be difficult and it is classified according to the following criteria:

- making certain analyses and comparisons of the ongoing financial statements with the ones of the previous year, as well as reviewing the previous tendencies;

- identifying unusual transactions, the company's inactivity, sudden changes of methods and policies, the oldness of debts, of stocks and claims, fictive transactions and reserves; 
- analysis of notes and annexes to the balance and comparing them to the previous years, particularly in case of the unusual gains, pensions and stocks;

- verifying the items relating to the increase and oldness of debts and of rates relating to the stocks sold;

- $\quad$ analysis of the difference between the results and the estimations by following the increase of the result per share;

- $\quad$ existence of stimulants and motivations at the level of the management;

- examination of the relationship between the cash flows and the exploitation activity;

verifying the crediting conditions, the results compensations, as well as comparing them with other companies of the area from the point of view of the financial trend.

\section{CONCLUSIONS}

By the actions undertaken in order to present a favourable image of the management, it is followed beside the attraction of funding sources, the enhancement of the position on the market, the promotion of an image reflecting the safety of the activity continuity and obtaining several materials uses.

The use of the management of results may have both negative and positive effects, all depends on how much the techniques are used and on the end purpose, in order to follow the priority of the company interest and not of the management.

The development of this phenomenon starts from the existence of the flexibility in legislation and accounting standards, in order to provide the possibility to choose for the variant that the management considers the most favourable, according to the criteria and predictions which must be met.

The use of the management of results decreases the users' trust in the financial and accounting information presented; that is why an approach for the mitigation of the phenomenon would be a detailed analysis of the situations presented in order to identify the possible anomalies.

Most often, the management of the results has negative effects, because it is used for the detriment of the company and for the benefit of the management, intending to obtain several gains associated to the accomplishment of certain performance criteria. Thus, the management of results cannot be associated with the idea of economic reality of the company, being more an illusion over what it is wanted to be, an illusion transformed in a false reality by the management of the company.

One first step to mitigate the use of this type of manipulation in accounting should be made both by the users of the financial and accounting information and by the regulatory bodies, by removing the flexibility to apply the norms. An important role should also be exercised by the company by introducing certain management contracts which do not provide the possibility to management to use such practices, but also by facilitating the controls.

\section{REFERENCES}

[1] Atik, A. (2009), „Detecting income-smoothing behaviors of Turkish listed companies through empirical tests using discretionary accounting changes". Critical Perspectives on Accounting, Volume 20, Issue 5, pp. 591-613 available on-line at: http://www.sciencedirect.com;

[2] Adrian Grosanu, Rachisan Paula Ramona and Berinde Sorin Romulus (2011) Study regarding the influence of Romanian accounting regulation on creative accounting techniques; Annals of Faculty of Economics, 2011, vol. 1, issue 2, pages 523-528;

[3] Agostini, Marisa and Favero, Giovanni, Accounting Fraud, Business Failure and Creative Auditing: A Micro-Analysis of the Strange Case of Sunbeam Corp. (September 20, 2012). Department of Management, Università Ca' Foscari Venezia Working Paper No. 12/2012. Available at SSRN: http://ssrn.com/abstract=2149552;

[4] Baker, C.R., Hayes. R, (2004) „Reflecting form over substance: the case of Enron Corp". Critical Perspectives on Accounting, Volume 15, Issues 6-7, pp. 767-785, available on-line at: http://www.sciencedirect.com;

[5] Benito, B., Montesinos, V., Bastida, F. (2008)- „An example of creative accounting in public sector: The private financing of infrastructures in Spain". Critical Perspectives on Accounting, Volume 19, Issue 7, Pages 963-986, available on-line at: http://www.sciencedirect.com;

[6] Dilip, K. S. (2006), 'Creative Accounting in Bangladesh and Global;

[7] Lambert, C., Sponem, S.,2005. Corporate governance and profit manipulation: a French field study. Critical Perspectives on Accounting, Volume 16, pp.717-748;

[8] Feleaga Niculae, Taming the accounting jungle, Economica, Bucharest, 1996;

[9] Feleaga N, Malciu L., Accounting policies and options, Economica, 2002 ;

[10] Gearin M., Khandelwal S., A true and fair view or mandatory standards? Australian Accountant, 1995, vol. 65, pp. 12-16;

[11] Goel A., Thakor A., Why do firm's smooth earnings? Journal of Business, 2003, vol. 76, no.1, pp. 151-192;

[12] Jones M., Creative accounting, Fraud and International Accounting Scandals, John Wiley and Sons Ltd, London, 2011;

[13] Loren Brandt, Johannes VAN BIESEBROECK, and Yifan ZHANG. "Creative Accounting or Creative Destruction? Firm-level Productivity Growth in Chinese Manufacturing" Journal of Development Economic $97.2 \quad$ (2012): 339-351. Available at: http://works.bepress.com/yfzhang/4;

[14] McBarnet D., Whelan C., Creative Accounting and the Cross-Eyed Javelin Thrower, John Wiley and Sons, Ltd., London, 1999, pp. 102;

[15] Naser, C. (1993). Creative financial accounting: its nature and use, Pretince Hall, quoted by Feleaga N., Malciu L., Accounting policies and options, Fair Accounting versus Bad Accounting, Economica, Bucharest, 2002;

[16] Nisulescu Ileana, Enterprise financing and restructuring, Infomedica Publishing House, Bucharest, 2000;

[17] Vinnari, E.M., Näsi, S., (2008) „Creative accrual accounting in the public sector: 'milking' water utilities to balance municipal budgets and accounts". Financial Accountability \& Management, Oxford, Vol. 24, Iss. 2; pg. 97, available on-line at: http://www.proquest.co.uk;

[18] Vladu Alina Beattrice and Adrian Grosanu (2011), Same insights regarding creative accounting in Romanian accounting environment-regulators, financial auditors and professional bodies opinion, Annals of Faculty of Economics, 2011;

[19] Watts, R.L., Zimmerman J.L., 1990. Positive accounting theory: A ten-year perspective, Accounting Review, 65, pp.131-156;

[20] Young M.R., Accounting Irregularities and Financial Fraud: A Corporate Governance Guide, 2000, pp. 13. 